\title{
Correction: Cracking the code for maintaining quality training in Olympic distance triathlon: lessons learnt from a squad of elite Scandinavian athletes
}

Corrie Myburgh, Tobias Hansen, Anders Holm Beck, et al. Cracking the code for maintaining quality training in Olympic distance triathlon: lessons learnt from a squad of elite Scandinavian athletes. BMJ Open Sport E Exercise Medicine 2017;3(1):e000274; DOI: 10.1136/bmjsem-2017-000274.

The authors would like to acknowledge the contribution of Martin Bager Bertelsen in the development of their visual communication tool for conveying the 'vortex concept' and furthermore for his efforts during interview data collection in this investigation.

Open Access This is an Open Access article distributed in accordance with the Creative Commons Attribution Non Commercial (CC BY-NC 4.0) license, which permits others to distribute, remix, adapt, build upon this work non-commercially, and license their derivative works on different terms, provided the original work is properly cited and the use is non-commercial. See: http://creativecommons.org/licenses/by-nc/4.0/

( ) Article author(s) (or their employer(s) unless otherwise stated in the text of the article) 2018. All rights reserved. No commercial use is permitted unless otherwise expressly granted.

BMJ Open Sport Exerc Med 2018;4:e000274corr1. doi:10.1136/bmjsem-2017-000274corr1

Check for updates 